\title{
Implementation of image processing techniques as a tool for form analysis of Romanian folk elements
}

DOI: 10.35530/IT.071.05.1690

\author{
LILIANA INDRIE \\ ZLATIN ZLATEV \\ DORINA-CAMELIA ILIES \\ AMALIA STURZA
}

MIHAELA DOCHIA

MARIA GOZNER

GRIGORE HERMAN

TUDOR CACIORA

\section{ABSTRACT - REZUMAT}

\section{Implementation of image processing techniques as a tool for form analysis of Romanian folk elements}

The present paper proposes a method for an effective analysis of Romanian folk motifs using two basic algorithms Radius-Vector function (RV) and Principal Component Analysis (PCA). For a better accuracy of the analysis, a combination of these methods has been proposed. The authors selected few Romanian folk motifs (embroidered on blouses, skirts called "poale", front aprons called "zadii", sleeveless vest) from Bihor, Arad, and Maramures Counties. The vectorization of traditional motifs was made by GIS software.

Keywords: traditional folk costumes, folk motives, Radius-Vector function, Principal Component Analysis (PCA)

\section{Implementarea tehnicilor de procesare a imaginilor ca instrument pentru analiza formei elementelor tradiționale românești}

Lucrarea de față propune o metodă pentru analiza eficientă a motivelor populare românești folosind doi algoritmi de bază - funcția Radius-Vector (RV) și Analiza componentelor principale (PCA). Pentru o mai bună precizie a analizei, a fost propusă o combinație a acestor metode. Autorii au selectat câteva motive tradiționale românești (brodate pe cămăși, poale, zadii, veste) din județele Bihor, Arad și Maramureș. Vectorizarea motivelor tradiționale a fost realizată folosind Software-ul GIS.

Cuvinte-cheie: costume populare tradiționale, motive populare, funcția Radius-Vector, Analiza componentelor principale (PCA)

\section{INTRODUCTION}

By its beauty and remarkable artistic value, the folk costumes can be transformed into the best ambassador of Romania. Unfortunately, today's authenticity is increasingly replaced by kitsch, the interest in preserving, putting to good use and transmitting the material of cultural treasure is fading away. Therefore, much of our cultural dowry is disappearing. Although they have a great variety of shapes and ornaments, the traditional costumes from Crisana (Bihor, Arad County) and Maramures have not been studied enough and exploited thoroughly. That is why we believe that we should do everything in our power to preserve the traditional motifs found in the costumes of these ethnographic areas, in order to preserve and promote them, thus saving them from being extinct. This approach is seen as a symbol for redeeming the past for a sustainable future of the traditional motives and a way to convey the love for the inherited beauty of the past, finally yet very important to develop the feeling of local pride.

The digitization of cultural heritage and Romanian traditional motifs is an activity that has gained great momentum over the past two decades together with the development of computing technology. Today it is very common to obtain vector information through digitization. Along with vectors and associated databases, the digital images have become the core component of GIS [1-3]. In recent years, GIS software has been used to map historical objects, restore artefacts and map folklore areas.

In the present paper, were analysed the traditional motifs (embroidered on shirts underskirts, apron, embroidered sheepskin vest or traditional pouches) from Bihor, Arad, and Maramures Counties, Romania. GIS software was used for vectorization of traditional motifs. This software is able to create vector features from raster interactively or with the help of automated tools, comparable to the quality of the results obtained with the more common software products used for this purpose, Inkscape, Adobe Illustrator, Corel Draw.

The main aim of this paper is to propose a method for effective analysis of Romanian traditional motifs. In the analysis of the folk elements, two basic algorithms - radius-vector function (RV) and principal component analysis (PCA) were used. In order to improve the accuracy of the analysis of these elements, a combination of these methods has been proposed. 


\section{MATERIAL AND METHODS}

\section{Material}

From Maramureș to Oltenia, from Banat to Dobrogea, from the Crișurilor county to Muntenia and Moldova, the Romanian costume unity manifests itself in all domains of its essential aspects. From the raw materials used, from the tailoring and the structure of the various pieces, up to the ornament used, the symbols sewn on Romanian folk costumes are classified into: vegetal symbols (fruits, flowers, leaves, plants); abstract symbols (anthropomorphic, zoomorphic or cosmic); geometric symbols (points, straight lines, interrupted lines, or zigzag lines, crossed lines, the rhombs, squares and triangles), and the chromatics is characterized by freshness and harmony $[4,5]$. With regard to the folk costumes from the western part of Romania, the line and the composition of the costume show some deviations from the authentic type of Romanian clothing by the white cotton skirt that is wide and creased, the apron that is only worn in front and with the short shirt worn without a girdle, and large men tights (long peasant trousers) [4]. However, the ornamentation of Romanian traditional motifs and technical systems of seams and fabrics is preserved [4, 6-10].

The motifs of the folk costumes from Crisana (Bihor and Arad) and Maramures were vectorized, motives that were found embroidered on blouses, skirts called „poale”, front aprons called „zadii”, sleeveless vest (30 traditional motifs/region or a total of 90 elements). Figures 2, 3 and 4 represent the folk elements that were used. The GIS system was used for vectorization of folk elements.

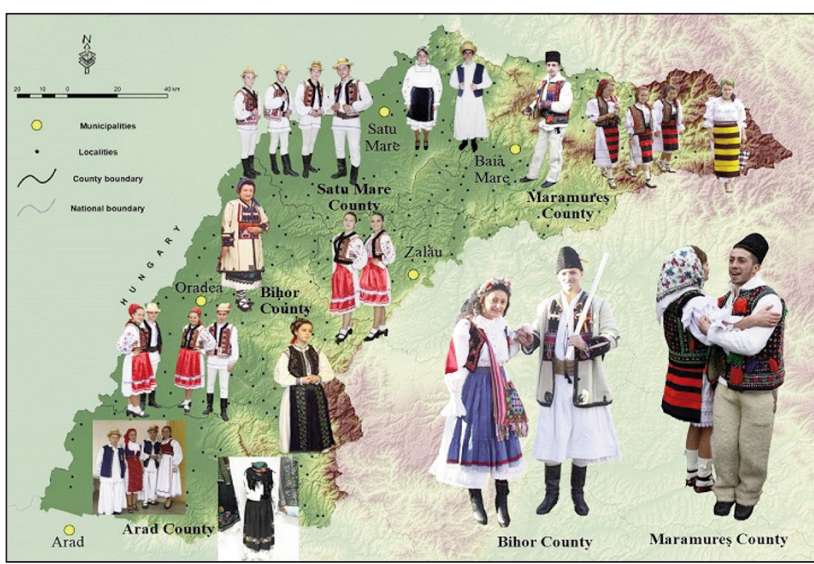

Fig. 1. Map of the studied folk costumes from (Bihor, Arad and Maramureș) [9]

Folk elements from Bihor County are presented in figure 2 .

Folk elements from Arad County are presented in figure 3 .

Folk elements from Maramures County are presented in figure 4.

\section{Methods}

In the present work, a survey was conducted on consumer opinion. In order to assess the forms of Romanian folklore elements 180 respondents from Romania filled in the survey. They were arbitrarily chosen no matter of their age, work, gender, education, employment. All respondents know the reason for the survey and the motivation behind using the information that was obtained. The study was led through a Google Forms survey, since it is a free Google

\begin{tabular}{|c|c|c|c|c|c|c|c|c|c|}
\hline$\frac{6}{7} 2$ & $z^{*}$ & $\mathrm{xH} / \mathrm{AS}$ & 1 & 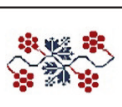 & 影 & 商 & $x^{\underline{k}}$ & 24 & $5 / \mathrm{g}$ \\
\hline 1 & 2 & 3 & 4 & 5 & 6 & 7 & 8 & 9 & 10 \\
\hline 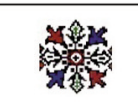 & $\$$ & 龍 & $1 / 8$ & \$ & ges & 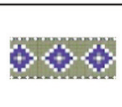 & Yy & No & \\
\hline 11 & 12 & 13 & 14 & 15 & 16 & 17 & 18 & 19 & 20 \\
\hline 4 & 䊑垱 & $x$ & 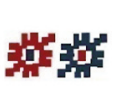 & th & 6 & " & 3 & 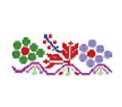 & sase \\
\hline 21 & 22 & 23 & 24 & 25 & 26 & 27 & 28 & 29 & 30 \\
\hline
\end{tabular}

Fig. 2. Folk elements from Bihor County

\begin{tabular}{|c|c|c|c|c|c|c|c|c|c|}
\hline 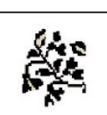 & 感 & $8 \% \& \&$ & 8 & $B$ & sete & A & 战 & & 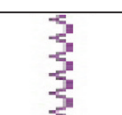 \\
\hline 1 & 2 & 3 & 4 & 5 & 6 & 7 & 8 & 9 & 10 \\
\hline Dos & 壁 & 勱 & 橴 & se & $3 x$ & 窟䍌 & ast & Af & Drext \\
\hline 11 & 12 & 13 & 14 & 15 & 16 & 17 & 18 & 19 & 20 \\
\hline 68 & 呚 & $y$ & 6 & 1 & 6 & 部 &  & 8 & \\
\hline 21 & 22 & 23 & 24 & 25 & 26 & 27 & 28 & 29 & 30 \\
\hline
\end{tabular}

Fig. 3. Folk elements from Arad County 


\begin{tabular}{|c|c|c|c|c|c|c|c|c|c|}
\hline 4 & & $4+3 x$ & 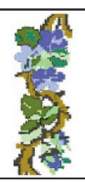 & ह5 & a & 3 & $\sum^{*}$ & $\frac{3}{53}$ & \\
\hline 1 & 2 & 3 & 4 & 5 & 6 & 7 & 8 & 9 & 10 \\
\hline$\frac{8}{6}$ & aी & : & t & & in & 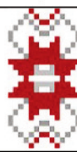 & 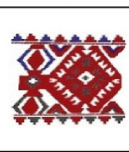 & $\frac{3}{3 k}$ & (3) \\
\hline 11 & 12 & 13 & 14 & 15 & 16 & 17 & 18 & 19 & 20 \\
\hline 8 & $\$ 8$ & 8 & 㴽 & $y$ & 8 & 3 & $x$ & $\square \mathrm{CH}$ & \\
\hline 21 & 22 & 23 & 24 & 25 & 26 & 27 & 28 & 29 & 30 \\
\hline
\end{tabular}

Fig. 4. Folk elements from Maramures County

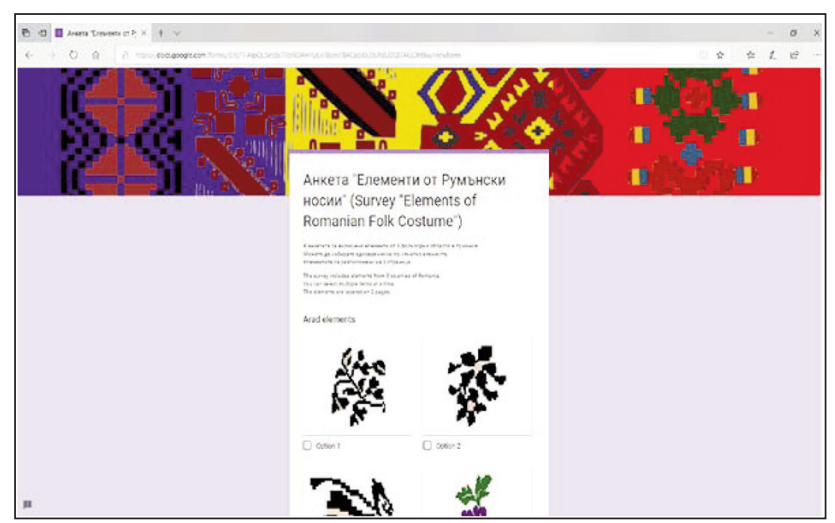

Fig. 5. Survey in Google Forms

online tool application that can be conducted on the Internet by a cell phone, tablet or a desktop computer. The results are processed by the $A B C$ investigation technique [11]. The information is gathered into three classes A, B and C. In class A fall $0-75 \%$ of the data, $75-95 \%$ in class $B$ and $95-100 \%$ in class $C$. The elements that fall into class $A$ have the highest percentage of choice by respondents. In the analysis of the folk elements, two basic algorithms are used: radius vector function (RV) and principal component analysis (PCA). A combination of these methods is proposed in order to improve the accuracy of the analysis of this element's analysis.
Descriptions by radius - vector function

A radius vector function is used that reflects the vector's magnitude dependence from a particular point in the interior of the object at any point of the boundary to its slope relative to the positive axis $X$ of the coordinate system [12]. The radius vector function is typically assumed to be the distance from a reference point that is the center of mass to the contour $[12,13]$. When the slope $\theta$ varies from $0^{\circ}$ to $360^{\circ}$, then the vector fully traverses the boundary of the contour, and the resulting function $R=f(\theta)$, where $R$ is the vector size and it can be used as a description of the shape of the object [13].

The radii of the center of mass are calculated for each individual point in the contour of the object:

$$
r_{i}(\theta)=\sqrt{\left(x_{1}-x_{i}\right)^{2}+\left(y_{1}-y_{i}\right)^{2}}, i=1 \ldots 360
$$

where $r_{i}$ is the radius at a given angle $\theta, x_{1}, y_{1}$-coordinates of the object's center of gravity, $x_{i}, y_{i}$ - coordinates of a point on the outline of the object.

The actions on this phase are repeated, with the slope $\theta$ changing from $0^{\circ}$ to $360^{\circ}$. From each value of $\theta$, the found value of $r$ and the coordinates $\left(x_{i}, y_{i}\right)$ of the relevant point of the boundary of the object are remembered. Thus, the radius vector function $R=f(\theta)$ for the particular object is obtained in tabular form. Stages of an algorithm for radius-vector function are presented in figure 6 . From the original image $B$ (RGB) component is extracted. Then it is converted

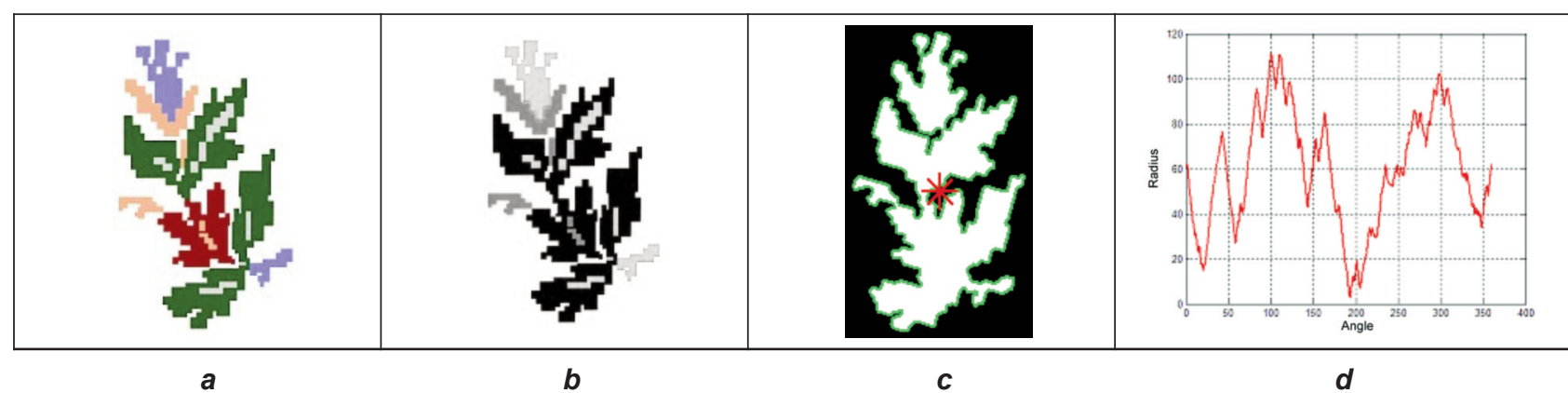

Fig. 6. An algorithm for extraction of Radius-vector function: $a$ - original image; $b-\mathrm{B}(\mathrm{RGB})$ colour component; $c$ - image re-orientation, contour and centroid; $d$ - radius-vector function 
to a binary image with threshold 0.9. Filter with type "disk" is used with radius 2 . Radius-vector function is calculated according to methodology, presented in [14]. Parameters that describe folk elements are calculated according to formulas in table 1, where: d-short axis; $D$ - long axis; $A_{e}$ - element area; $P_{e}$ - perimeter; $A_{\text {ideal }}$ - ideal area of an ellipse, calculated by short and long axis; $A_{m r}$ - area of a minimum rectangle, calculated by long and short axes.

The principal component analysis uses an orthogonal transformation to convert a set of observations of possibly correlated variables into a set of values of linearly uncorrelated variables called principal components [15].

The principal component analysis creates an orthogonal coordinate system where the axes are arranged according to the dispersion in the original data to which the relevant major component and the dispersions in the principal values refer. In the data covariance matrix $K$ :

$$
K=E\left[(x-\bar{x})^{T}[(x-\bar{x})]\right.
$$

The simple variant of PCA has some disadvantages if data is highly overlapped.

PCA method is used to reduce the amount of data and analysis of the radius-vector functions and for the selection of informative coefficients that describe the form of folklore elements [15].

All of the analysis was made with a level of significance alpha $=0.05$.

\section{RESULTS AND DISCUSSION}

The results for calculated parameters of the elements are presented in table 2. Coefficient of variation (CV) is calculated as a ratio between standard deviation (SD) and mean value of the elements ( $C V=S D /$ mean). If it is under $30 \%$ then the values of parameters are close to one another. It is clearly seen that areas ratios have coefficient of variation under $30 \%$, which means that the folk elements from these three Romanian regions have the same area ratios. The analysed elements significantly differ in their coefficients as form, eccentricity, ovality. PCA analysis of the coefficients that describe folk elements show that $K f$ (coefficient of form) and K1 (eccentricity) describe $99 \%$ of the variance of the data. These coefficients are significant for analysis of consumer choices

\begin{tabular}{|c|c|c|c|c|c|c|c|}
\hline \multicolumn{8}{|c|}{ PARAMETERS OF FOLK ELEMENTS } \\
\hline County & $\begin{array}{l}\text { Descriptive } \\
\text { statistics }\end{array}$ & Kf & K1 & c & $\mathbf{R}$ & KA & KAM \\
\hline \multirow{5}{*}{ Arad } & $\min$ & 86.85 & 105.13 & 6.91 & 0.02 & 0.50 & 0.39 \\
\hline & $\max$ & 618.65 & 252.24 & 49.23 & 0.14 & 0.96 & 0.75 \\
\hline & mean & 266.77 & 158.20 & 21.23 & 0.06 & 0.70 & 0.55 \\
\hline & SD & 133.24 & 40.07 & 10.60 & 0.03 & 0.10 & 0.08 \\
\hline & $\mathrm{CV}$ & 0.50 & 0.25 & 0.50 & 0.54 & 0.15 & 0.15 \\
\hline \multirow{5}{*}{ Bihor } & $\min$ & 38.91 & 105.38 & 3.10 & 0.01 & 0.37 & 0.29 \\
\hline & $\max$ & 860.41 & 685.24 & 68.47 & 0.32 & 0.94 & 0.74 \\
\hline & mean & 300.35 & 188.55 & 23.90 & 0.08 & 0.65 & 0.51 \\
\hline & SD & 218.58 & 124.59 & 17.39 & 0.08 & 0.16 & 0.12 \\
\hline & $\mathrm{CV}$ & 0.73 & 0.66 & 0.73 & 0.97 & 0.24 & 0.24 \\
\hline \multirow{5}{*}{ Maramures } & $\min$ & 35.23 & 109.75 & 2.80 & 0.03 & 0.37 & 0.29 \\
\hline & $\max$ & 492.93 & 557.75 & 39.23 & 0.36 & 0.94 & 0.74 \\
\hline & mean & 138.86 & 255.67 & 11.05 & 0.14 & 0.78 & 0.61 \\
\hline & SD & 102.49 & 149.47 & 8.16 & 0.09 & 0.14 & 0.11 \\
\hline & $\mathrm{CV}$ & 0.74 & 0.58 & 0.74 & 0.63 & 0.18 & 0.18 \\
\hline
\end{tabular}

Note: Kf - coefficient of form; K1 - eccentricity; c - ovality; $\mathrm{R}$ - roundness; KA - area ratio; KAM - area ratio; min - minimum; max - maximum; SD - standard deviation; CV - coefficient of variation. 


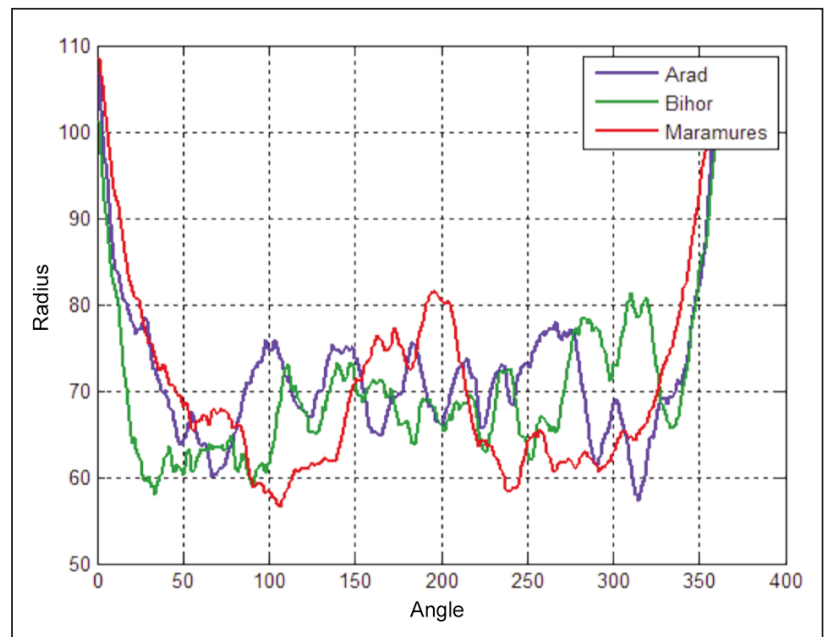

Fig. 7. Mean values of radius-vector functions of elements from three Romanian Counties

of elements. According to the results obtained by $A B C$ analysis, Arad elements with $K f=245.77 \pm 133.96$ and $K 1=164.62 \pm 42.59$ (mean \pm standard deviation) are most selected by respondents from the survey. $K f=418.72 \pm 239.96$ and $K 1=238.82 \pm 174.84$ for Bihor elements, $K f=173.93 \pm 124.32$ and $K 1=210.09 \pm$ \pm 63.23 for Maramures. These results correspond to those obtained in other Balkan countries, presented in [16] where authors have found that consumers in Bulgaria prefer folklore elements with a high value of coefficient of form.

Mean values of radius vector functions of elements from three Romanian counties are presented in figure 7 . The radius-vector functions differ just like the other parameters that describe folklore elements. The elements of Arad and Bihor have close radius vector functions, whereas those from Maramures differ from the other two areas. Arad and Bihor are near on the map, and their form descriptions have visually the same character of change. It is hard to distinguish the elements from these three regions directly by their RVs.

To reduce the amount of data of the RVs, principal components - simple (PCA) was used. First three principal components describe $97.4 \%$ of the variance of radius-vector functions that is why the first three components are chosen. Figure 8 presents the results from principal component analysis of radius-vector functions. When using a simple variant of PCA in the separation of folk elements classes - their region of origin, the obtained results prove the statement of Haenlein [17] that the simple PCA variables are strongly dependent and directly correspond to raw data.

The folklore elements most selected by respondents in the survey, with a higher percentage of choice, are presented in the material and methods part.

The method proposed here for the analysis of consumer opinion by reduced data of radius-vector functions of folklore elements improves the methods of analysis proposed by [16] and [18], where the authors use forms and radius-vector functions only as descriptors of folklore elements that can be used for their storage in specialised databases. The method proposed here uses less amount of data - only three principal components for every folklore element and it is also a suitable tool for analyzing the consumer opinion needing less processing time, for example 10 seconds in direct implementation of radius-vector functions, compared to 3 seconds with 3 principal components for every element.

\section{CONCLUSION}

The results obtained represent a key feature in the use of PCA. Its effectiveness depends mainly on the object being studied and the methods used to reduce the amount of data.

A combination between radius-vector function and PCA has been proposed in the analysis of folk elements and consumer preferences. This combination is a new tool for the analysis of these elements considering the reduction of the amount of data. The practical implementation of the results obtained in this paper is going to solve the problem that most of the results presented in the articles published so far could not solve, meaning that they only contain theoretical aspects and do not aim to analyse the traditional motifs. Vectorization of folklore elements from raster images will improve the analysis of the external aspect of the traditional motifs analysed according to their size, shape, color, condition and lack of visual defects.

In order to reduce the amount of data and accelerate the computational process, in the future, the method

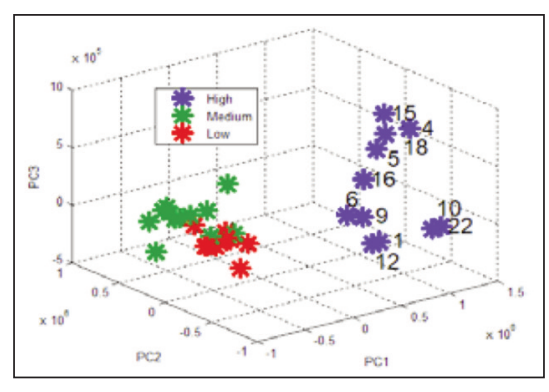

a

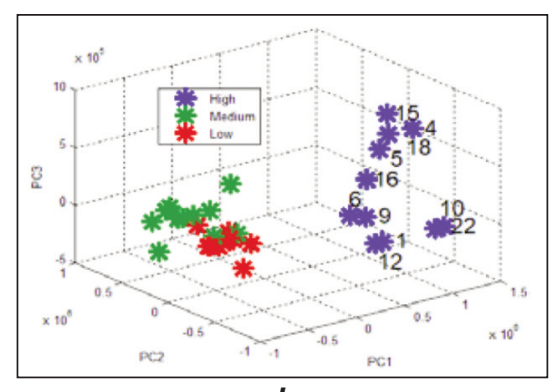

b

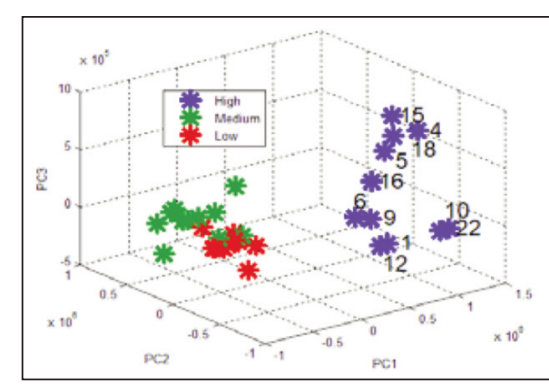

c

Fig. 8. Principal component analysis of radius-vector functions: $a$ - Arad; $b$ - Bihor; $c$ - Maramures 
can be used in digital databases containing a collection of Romanian folk elements.

\section{ACKNOWLEDGMENTS}

Special thanks to Violeta Gherman, Irina Avram, Dana Tomsa, Maria Aiftincăi ("Marițuca” Ethnography Museum from Vladimirescu) who supplied us the traditional folk costumes from Bihor, Arad and Maramures Counties, which helped us a lot and providing us with a wonderful source of valuable information. The research was possible by equal scientific involvement of all authors.

\section{REFERENCES}

[1] Herman, G.V., Using Geographical Information (GIS) System for Management of Flood Risks in the Somes Plain, In: Cross-Border Partnership with Special Regard to the Hungarian - Romanian - Ukrainian Tripartite Border, Book Editors Ioan Horga, Istvan Suli Zakar, Publishing House University of Debrecen Press, 2010, ISBN 978-606-100153-8, 175-179

[2] Romocea, T., Oneț, A., Sabău, N.C., Oneț, C., Herman, G.V., Pantea, E., Change of the groundwater quality from industrial area Oradea, Romania, using Geographic Information Systems (GIS), In: Environmental Engineering \& Management Journal (EEMJ), 2018, 17, 9, 2189-2199

[3] Ilieș, A., Wendt, J.A, Ilieș, D.C., Herman, G.V., Ilieș, M., Deac, A.L., The patrimony of wooden churches, built between 1531 and 2015, in the Land of Maramureș, Romania, In: Journal of Maps, 2016, 12, 597-602

[4] Romanian Folk Costumes, by Ethnographic Regions, Available at: http://www.romanianmuseum.com/Romania/ aboutRomania.html [Accessed on December 1st 2018]

[5] Mocenco, A., Olaru, S., Popescu, G., Ghituleasa, C., Romanian folklore motifs in fashion design, In: Annals of the University of Oradea, Fascicle of Textiles, Leatherwork, 2014, XV, 1, 63-68

[6] Dunăre, N., Port popular din Bihor, Editura de stat pentru literatură şi artă, Bucharest, 1957

[7] Colta, R., Portul popular din judeţul Arad, Editura Etnologică București, 2014, ISBN 978-973-8920-69-9, Available at: https://vdocuments.net/elena-rodica-colta-portul-popular-din-judetul-arad-editura-.html [Accessed on December 1st 2018]

[8] Dogaru, O., Ornamentele si croitul costumului popular din județul Maramureș, Editura Comitetului de Cultura si Educatie Socialista al Judetului Maramures. Centrul de indrumarea a creatiei populare si a miscarii artistice de masa, 1984, 201

[9] Ilies, A. (coordinator), Baias, S., Baias, I., Blaga, L., Buhaș, S., Chiriac, A., Ciocan, J., Dăncuș, M., Deac, A., Dragoș, P., Dumitrescu, G., Gaceu, O., Godea, I., Gozner, Maria, Grama, V., Herman, G., Hodor, N., Hurley, P., Ilieș, D., Ilieș, G., Ilieș, M., Josan, I., Leșe, G., Măduța, F., Mojolic, D., Morar, C., Olaru, M., Stașac, M., Stupariu, M., Sturza, A., Ștefănescu, B., Tătar, C., Vârnav, R., Vlaicu, M., Wendt, J., Crisana-Maramures. Atlas geografic al patrimoniului turistic/Geographical atlas of tourism heritage, Editura Universității din Oradea, 2014, ISBN 978-60610-1298, 302

[10] Indrie, L., Stan, O., Doble, L., Romanian traditional patterns reinterpreted and stylized using computer graphics programs, International Conference eRA-10, 2015, 48-52, Textile and wearable technologies session, 23-25 September 2015, Atena, Greece

[11] Chandra Bose, D., Inventory management, PHI Learning Private Limited, New Delhi, India, 2006, ISBN-81-2032853-1

[12] Kang, S., Ahmad, M., Chun, J., Kim, P., Park, J., Modified Radius-Vector Function for Shape Contour Description, In: Laganá, A., Gavrilova, M.L., Kumar, V., Mun, Y., Tan, C.J.K., Gervasi, O., (eds) Computational Science and Its Applications - ICCSA 2004, ICCSA 2004, Lecture Notes in Computer Science, 2004, 3046, 940-947

[13] Pavlidis, T., Algoritms for Shape Analysis of Contours and Waveforms. In: IEEE Trans, Pattern Analysis and Machine Intelligence, 1980, 2, 4, 301-312

[14] Penchev, S., Shape Description of Grain Sample Elements, In: Proceedings of Anniversary Scientific Conference "40 Years Department of Industrial Automation", University of Chemical Technology and Metallurgy, Bulgaria, 2011, $125-128$

[15] Mladenov, M., Penchev, S., Deyanov, M., Complex assessment of food products quality using analysis of visual images, spectrophotometric and hyperspectral characteristics, In: International Journal of Engineering and Innovative Technology (IJEIT), ISSN: 2277-3754, 2015, 4, 12, 23-32

[16] Elnashar, E., Zlatev, Z., İşmal, Ö., Mahale, G., Bulgarian national folk elements for the contemporary fashion, In: Innovation and entrepreneurship, 2017, 5, 2, 78-88

[17] Haenlein, M., A Beginner's Guide to Partial Least Squares Analysis, In: Understanding Statistics, 2004, 3, 4, 283-297

[18] Zlatev, Z., Dolapchieva, G., Processing and analysis of images of folk costume from southeastern Thrace, In: Textile and apparel, 2017, 8 (LXIV), 16-22 
Authors:

LILIANA INDRIE ${ }^{1}$, ZLATIN ZLATEV², DORINA CAMELIA ILIES ${ }^{3}$, AMALIA STURZA ${ }^{4}$, MIHAELA DOCHIA ${ }^{5}$, MARIA GOZNER ${ }^{3}$, GRIGORE HERMAN ${ }^{3}$, TUDOR CACIORA ${ }^{3}$

${ }^{1}$ University of Oradea, Faculty of Energy Engineering and Industrial Management, Department of Textiles, Leather and Industrial Management, B.St. Delavrancea Str., no. 4, 410058, Oradea, Romania

${ }^{2}$ Trakia University, Faculty of Technics and Technologies, 38 Graf Ignatiev str., 8602, Yambol, Bulgaria e-mail: zlatin.zlatev@trakia-uni.bg

${ }^{3}$ University of Oradea, Faculty of Geography, Tourism and Sport, $1^{\text {st }}$ University Street, 410087, Oradea, Romania e-mail: iliesdorina@yahoo.com, mariagozner@yahoo.com, grigoreherman@yahoo.com, tudor.caciora@yahoo.com

${ }^{4}$ University of Oradea, Faculty of Civil Engineering, Cadastral Survey and Architecture, Department of Cadastral Survey, B.St. Delavrancea str. No. 4, 410058, Oradea, Romania e-mail: amasturza@yahoo.com

5"Aurel Vlaicu" University of Arad, Research Development Innovation in Technical and Natural Science Institute, 2-4 Elena Dragoi Street, 310330, Arad, Romania e-mail: dochiamihaela@yahoo.com

Corresponding author:

LILIANA INDRIE

e-mail: liliindrie@yahoo.com 